\title{
PENGARUH PIJAT WOLLWICH TERHADAP RERATA PRODUKSI ASI PADA IBU POSTPARTUM DI PMB LUSI KABUPATEN BANDUNG PADA TAHUN 2021
}

\author{
Trianawati $L^{1}$, Tohri $T^{2}$, Mulyani $I^{3}$ \\ ${ }^{1,2,3}$ Institut Kesehatan Rajawali, Fakultas Kebidanan
}

\section{ARTICLE INFORMATION}

Received: October, 14, 2021

Accepted: February, 07, 2022

Available online: February, 08, 2022

\section{KATA KUNCI}

Pijat Woolwich, Produksi ASI

\section{CORRESPONDENCE}

E-mail:

$\underline{\text { lusitrianawati89@gmail.com }}$

\section{A B S T R A C T}

\begin{abstract}
Background: Many things can cause failure in the breastfeeding process, it can be from mother factors, baby factors or other problems. One of the main causes of this failure from maternal factors is anxiety, lack of confidence and mother's fear of lack of milk production. Therefore, it is necessary to make efforts to overcome these problems, one of which is the Wollwich massage method. The Wollwich massage method is a pleasant form of touch therapy, gently stimulating the nipples to cause oxytocin secretion. Objective: This study aims to determine how much influence Wollwich massage has on breast milk production in 6-hour postpartum mothers at PMB Lusi, Bandung Regency in 2021. Methods: This research is an experimental study that uses a quasi-experimental study with a nonequivalent control group design. The sample in this study were all 6hour postpartum mothers who gave birth normally at PMB Lusi, the period April-June 2021 as many as 30 people. Where the total sample is divided into 2 groups, namely the intervention group / given treatment and control group / not given treatment. Data analysis using Wilcoxon test and Mann Whitney test. Results: The average milk production after giving Woolwich massage in the intervention group was $0.68 \mathrm{cc}$, the average milk production after giving breast massage in the control group was $0.29 \mathrm{cc}$ and there were differences in the average milk production between postpartum mothers in the intervention group and the control group with p- value $0.002<(0.05)$.

Conclusion: There is an effect of Wollwich massage based on the average milk production produced in 6 hours postpartum mothers between the intervention group and the control group at PMB Lusi, Bandung Regency.
\end{abstract}

\begin{abstract}
A B S T R A K
Latar belakang: Banyak hal yang dapat menyebabkan kegagalan dalam proses menyusui, bisa dari faktor ibu, faktor bayi ataupun karena masalah lainnya. Salah satu penyebab utama kegagalan tersebut dari faktor ibu adalah kecemasan, rasa tidak percaya diri dan ketakutan ibu akan kurangnya produksi ASI. Maka dari itu perlu dilakukan upaya untuk mengatasi masalah tersebut, salah satunya yaitu dengan metode pijat wollwich. Metode pijat wollwich merupakan bentuk terapi sentuhan yang menyenangkan, merangsang puting dengan lembut sehingga dapat menyebabkan sekresi oksitosin. Tujuan: Penelitian ini bertujuan untuk mengetahui berapa besar pengaruh pijat Wollwich terhadap produksi ASI pada ibu postpartum 6 jam di PMB Lusi Kabupaten Bandung pada tahun 2021. Metode: Penelitian ini merupakan penelitian eksperimen yang menggunakan quasi experiment dengan nonequivalent control group design. Sampel dalam penelitian ini adalah seluruh ibu postpartum 6 jam yang telah melahirkan normal di PMB Lusi, periode bulan April-Juni 2021 sebanyak 30 orang. Dimana dari total sampel ini dibagi menjadi 2 kelompok yaitu kelompok intervensi/ yang diberikan perlakuan dan kelompok kontrol/ yang tidak diberikan perlakuan. Analisis data menggunakan uji Wilcoxon dan Mann Whitney test.

Hasil: Rerata produksi ASI sesudah pemberian pijat Woolwich pada kelompok intervensi yaitu $0,68 \mathrm{cc}$, Rerata produksi ASI sesudah pemberian massage payudara pada kelompok kontrol yaitu $0,29 \mathrm{cc}$ serta terdapat perbedaan rerata produksi ASI antara ibu postpartum kelompok intervensi dan kelompok kontrol dengan $p$-value $0,002<\alpha$ $(0,05)$. Simpulan: Terdapat pengaruh pijat wollwich berdasarkan rerata produksi ASI yang dihasilkan pada ibu postpartum 6 jam antara kelompok intervensi dan kelompok kontrol di PMB Lusi Kabupaten Bandung.
\end{abstract}


Available online at : http://ojs.rajawali.ac.id/index.php/JKR

\section{Jurnal Kesehatan Rajawali}

\begin{tabular}{l|l|} 
ISSN (Print) 2085-7764 ISSN (Online) 2776-558X \\
\hline
\end{tabular}

\section{PENDAHULUAN}

Air Susu Ibu (ASI) eksklusif adalah bayi hanya diberi ASI saja selama 6 bulan, tanpa tambahan cairan lain seperti susu formula, jeruk, madu, air teh dan air putih, serta tanpa tambahan makanan padat seperti pisang, bubur susu, biskuit, bubur nasi dan nasi tim (Kristiyansari, 2011). Upaya untuk mendukung peningkatan pemberian ASI Eksklusif dapat dilihat dari telah dikeluarkannya berbagai pengakuan atau kesepakatan baik yang bersifat global maupun nasional yang bertujuan melindungi, mempromosi, dan mendukung pemberian ASI. Dengan demikian, diharapkan setiap ibu di seluruh dunia dapat melaksanakan pemberian ASI dan setiap bayi diseluruh dunia memperoleh haknya mendapat ASI. Sesuai dengan tujuan Sustainable Development Goals (SDGs) ke-3 target ke-2 yaitu pada tahun 2030, mengakhiri kematian bayi dan balita yang dapat dicegah dengan seluruh negara berusaha menurunkan Angka Kematian Neonatal setidaknya hingga 12 per 1.000 Kelahiran Hidup (Kemenkes RI, 2015).

Banyak manfaat diperoleh dari pemberian Air Susu Ibu (ASI). ASI menjadi sumber gizi utama bagi bayi yang belum dapat mencerna makanan padat. Bayi yang disusui dengan ASI akan mendapatkan gizi terbaik yang tidak tergantikan bahkan oleh susu formula yang terbaik sekalipun. Pemberian ASI dapat menurunkan angka kesakitan bayi, mengoptimalkan pertumbuhan, membantu perkembangan kecerdasan. Selain itu, pemberian ASI juga memberikan sejumlah manfaat bagi ibu seperti membantu memperpanjang jarak kehamilan, dan terhindar dari kanker payudara dan ovarium, serta meningkatkan ikatan ibu dan bayi. Sayangnya sampai saat ini, masih sedikit ibu yang memberikan ASI eksklusif.

Cakupan pemberian ASI di Indonesia tahun 2019 sebesar $67,74 \%$, jika mengacu pada target nasional tahun 2019 sebesar 50\%, maka secara nasional meskipun cakupan ASI eksklusif pada bayi usia kurang dari 6 bulan sudah mencapai target nasional namun demikian masih ada sekitar $32,26 \%$ bayi usia kurang dari 6 bulan yang belum mendapatkan ASI eksklusif. Namun pada tahun 2018 cakupan ASI eksklusif yaitu sebesar 68,74 (Kemenkes RI, 2020). Pemberian ASI eksklusif pada bayi umur 0-6 bulan di Provinsi Jawa Barat pada tahun 2019 sebesar 63,35\% hal ini menunjukkan bahwa cakupan pemberian ASI eksklusif sudah melampaui taget cakupan nasional 50\% (Kemenkes RI, 2020). Sedangkan pada tahun 2018 cakupan ASI eksklusif di Jawa Barat sebesar $37,29 \%$ bayi yang mendapat ASI eksklusif sampai usia 6 bulan. Hal ini menunjukkan ada peningkatan yang cukup signifikan cakupan ASI eksklusif dari tahun 2018 ke tahun 2019, namun demikian pada tahun 2019 masih cukup banyak bayi usia 0-6 bulan yaitu sekitar 36,65 yang belum mendapatkan ASI eksklusif (Kemenkes RI, 2020).

Pencapaian ASI eksklusif pada bayi usia 0-6 bulan di Kabupaten Bandung pada tahun 2018 sebesar 63,28\% dan pada tahun 2019 bayi usia 0-6 bulan yang mendapatkan ASI eksklusif menjadi 63,84\%, hal ini berarti belum mencapai target Kementrian Kesehatan yang telah menerbitkan Surat Keputusan Menteri Kesehatan Nomor 450/Menkes/SK/IV/2004 tentang pemberian ASI secara eksklusif pada bayi di Indonesia sebesar $80 \%$ (Dinkes Provinsi Jawa Barat, 2019).

Salah satu penyebab rendahnya cakupan pemberian ASI eksklusif bagi bayi dibawah usia enam bulan karena produksi ASI pada ibu postpartum yang terhambat pada hari-hari pertama pasca persalinan sehingga sebagian besar bayi mendapatkan susu formula pada saat baru lahir (Riskesdas, 2018). Tidak semua ibu postpartum langsung mengeluarkan ASI karena pengeluaran ASI merupakan suatu interaksi yang sangat komplek antara rangsangan mekanik, saraf dan bermacam-macam hormon yang berpengaruh terhadap pengeluaran oksitosin. Pengeluaran hormon oksitosin selain dipengaruh oleh isapan bayi juga dipengaruhi oleh reseptor yang terletak pada sistem duktus, bila duktus melebar atau menjadi lunak maka secara reflektoris dikeluarkan oksitosin oleh hipofise yang berperan untuk memeras air susu dari alveoli (Soetjiningsih, 2015).

Menurut Pamuji (2014), salah satu upaya yang dapat dilakukan untuk merangsang hormon prolaktin dan oksitosin pada ibu setelah melahirkan adalah dengan menimbulkan perasaan relaks pada ibu yaitu dengan memijat dengan woolwich dapat merangsang syaraf sel-sel di payudara, yang ditransmisikan ke hipotalamus dan ditanggapi oleh kelenjar hipofisis. Sebelum mengeluarkan hormon prolaktin, darah akan mengalir ke sel-sel epitel payudara untuk memproduksi ASI. Untuk mencegah dan mengobati masalah laktasi, seseorang dapat melakukan intervensi, khususnya pijat Woolwich, yang didasarkan pada pengamatan bahwa aliran ASI lebih penting daripada sekresi kelenjar susu. Pemijatan dilakukan pada daerah sinus lakrimalis, tepatnya $11,5 \mathrm{~cm}$ di atas areola, dengan 
tujuan untuk mengeluarkan susu dari sinus lakrimalis (Pamuji, 2014 ).

Hasil penelitian ini sejalan dengan hasil penelitian yang dilakukan oleh Sukriana (2018), hasil analisis menunjukkan bahwa rata-rata volume ASI setelah perlakuan pijat lenwich pada kelompok eksperimen adalah 80,92 ml dengan standar deviasi. adalah ,33 ml, sedangkan rata-rata volume ASI kelompok kontrol adalah 66,82 ml dengan standar deviasi ,39 ml. Perbedaan nilai rata-rata setelah pengujian antara kelompok eksperimen dan kontrol adalah $1,1 \mathrm{ml}$. Hasil analisis p-value $=0,000$ etlt; $(0,05)$, dapat disimpulkan bahwa ada pengaruh pijat Woolwich terhadap produksi ASI dan ada perbedaan produksi ASI antara kelompok intervensi dan kontrol.

Tujuan peneliti ini secara umum untuk mengetahui pengaruh pijat Woolwich terhadap produksi ASI pada ibu postpartum di PMB Lusi Kabupaten Bandung pada tahun 2021.

\section{METODE}

Penelitian dilakukan menggunakan desain quasi experiment dengan nonequivalent control group design menggunakan dua kelompok subyek (kelompok intervensi dan kelompok kontrol), dimana variabel penelitian diukur pada saat sebelum dan setelah dilakukan intervensi. Pengaruh intervensi dapat dilihat dari hasil pengolahan data, disini terdapat perbedaan dari hasil pengukuran kemudian dibandingkan dengan kelompok kontrol (Saryono, 2011). Populasi pada penelitian ini adalah seluruh ibu post partum 6 jam yang telah melahirkan normal di PMB Lusi Kabupaten Bandung, periode AprilJuni 2021 yaitu sebanyak 30 orang. Dimana dari total sampel ini dibagi menjadi 2 kelompok yaitu kelompok intervensi/ yang diberikan perlakuan dan kelompok kontrol/ yang tidak diberikan perlakuan. Analisis data menggunakan uji Wilcoxon dan Mann Whitney test.

Sampel adalah bagian dari populasi yang dianggap mewakili populasinya. Sampel dalam penelitian ini diambil dengan menggunakan teknik total sampling atau sampling jenuh, dimana semua anggota populasi dijadikan sampel penelitan. Jadi jumlah sampel dalam penelitian ini sebesar 30 orang yang dibagi menjadi 2 kelompok yaitu 15 responden untuk masing-masing kelompok, dengan Kriteria Inklusi. Kriteria inklusi adalah kriteria atau ciri-ciri yang perlu dipenuhi oleh setiap anggota populasi yang dapat diambil sebagai sampel (Notoatmodjo, 2018). Kriteria inklusi dalam penelitian ini adalah :

a. Ibu Post Partum 6 jam yang melakukan persalinan normal di PMB Lusi Kabupaten Bandung tahun 2021

b. Bentuk payudara normal/ tidak ada kelainan baik secara anatomis maupun fisiologi

\section{Variabel yang digunakan dalam penelitian :}

a. Variabel Independen (Variabel Bebas)

Variabel Independent dalam penelitian ini adalah pijat Woolwich.

b. Variabel Dependen (Variable Terikat)

Variabel terikat atau variabel dependent dalam penelitian ini adalah produksi ASI.

\section{Analisis Data}

a. Analisis Univariat

Analisis data univariat dilakukan terhadap tiap variabel dari hasil penelitian. Analisis univariat dalam penelitian ini dilakukan untuk mengetahui jumlah ASI yang dikeluarkan oleh responden sesudah diberikan terapi pijat Woolwich pada kelompok intervensi.

\section{b. Analisis Bivariat}

Menurut Notoatmodjo (2018), analisis bivariat dilakukan terhadap dua variabel yang diduga berhubungan atau berkolerasi dengan variabel independen (pijat Woolwich) terhadap variabel dependen (produksi ASI).

Sebelum melakukan uji analisis bivariat, peneliti melakukan uji normalitas data terlebih dahulu untuk mengetahui apakah data mempunyai distribusi normal atau tidak. Secara analisis dapat menggunakan uji kenormalan distribusi data, yaitu dengan melihat nilai Skewness : nilai mean dengan ketentuan jika nilai berada direntang $<-2$ hingga $<$ 2 maka data dikatakan berdistribusi normal. Hasil uji normalitas data, menunjukkan nilai skewness $2.460: 0,427$ (nilai standar error) $=5,7$ lebih besar dari (>) -2 s.d 2 (batas nilai normal) dengan demikian maka dapat disimpulkan bahwa distribusi data tidak normal, maka uji statistik yang digunakan dalam penelitian ini menggunakan uji non parametrik Wilcoxon untuk melihat perbedaan nilai rata-rata produksi ASI pada kelompok intervensi dan kelompok kontrol. Selanjutnya untuk tujuan mengetahui perbedaan rata-rata produksi ASI pada kedua kelompok, maka uji statistik yang digunakan adalah uji non parametrik mann whitney test, dengan batasan kemaknaan $5 \%$. 
HASIL

Tabel 1

Rerata Produksi Asi Pada Ibu Postpartum 6 Jam Kelompok Intervensi

\begin{tabular}{|c|c|c|c|c|c|c|}
\hline Produksi & $N$ & Minimum & Maximum & Mean & $Z$ & $\begin{array}{l}p \text { - } \\
\text { value }\end{array}$ \\
\hline Pretes & 15 & $0,04 c c$ & $2 c c$ & $\begin{array}{l}0,37 \\
c c\end{array}$ & & \\
\hline Postes & 15 & $0,15 c c$ & $3 c c$ & $\begin{array}{l}0,68 \\
c c\end{array}$ & 2,614 & 0,009 \\
\hline
\end{tabular}

(Sumber : Data Primer, 2021)

Berdasarkan tabel 1, dapat diketahui bahwa dari 15 ibu postpartum setelah dilakukan pijat woolwich, rerata produksi ASI adalah 0,68 cc.

Berdasarkan analisis uji statistic Wilcoxon Signed Rank Test untuk mengetahui adanya perbedaan produksi ASI pada ibu postpartum kelompok intervensi sebelum dan sesudah dilakukan pijat woolwich diperoleh bahwa besarnya nilai $\mathrm{Z}$ adalah $-2,614$ dengan nilai signifikan ( $p=$ value) sebesar 0,009 dimana nilai probabilitas 0,009 kurang dari nilai $a<0,05$, maka dengan ini hipotesis pada penelitian diterima, bahwa rerata produksi ASI sesudah dilakukan pijat woolwich pada ibu post partum kelompok intervensi yaitu $0.68 \mathrm{cc}$.

Tabel 2 Rerata Produksi Asi Pada Ibu Postpartum 6

\begin{tabular}{|c|c|c|c|c|c|c|}
\hline $\begin{array}{l}\text { Produks } \\
\text { i }\end{array}$ & $\mathbf{N}$ & $\underset{\mathbf{m}}{\text { Minimu }}$ & $\begin{array}{c}\text { Maximu } \\
\text { m }\end{array}$ & $\begin{array}{c}\text { Mea } \\
\mathbf{n}\end{array}$ & $\begin{array}{l}\mathbf{Z} \\
-\end{array}$ & $\begin{array}{l}\text { p- } \\
\text { valu } \\
\text { e }\end{array}$ \\
\hline Pretes & $\begin{array}{l}1 \\
5\end{array}$ & $0,00 \mathrm{cc}$ & $1,5 \mathrm{cc}$ & $\begin{array}{c}0,25 \\
\mathrm{cc}\end{array}$ & & \\
\hline Postes & $\begin{array}{l}1 \\
5\end{array}$ & $0,00 \mathrm{cc}$ & $1,5 \mathrm{cc}$ & $\begin{array}{c}0,29 \\
\mathrm{cc}\end{array}$ & $\begin{array}{c}2,28 \\
6\end{array}$ & $\begin{array}{c}0,02 \\
2\end{array}$ \\
\hline
\end{tabular}

Jam Kelompok Kontrol

Berdasarkan tabel 2, dapat diketahui bahwa dari 15 ibu postpartum pada kelompok kontrol setelah dilakukan massage pada payudara rerata produksi ASI adalah 0,29 cc.

Berdasarkan analisis uji statistic Wilcoxon Signed Rank Test untuk mengetahui adanya perbedaan produksi ASI pada ibu postpartum kelompok kontrol sebelum dan sesudah dilakukan massage pada payudara diperoleh bahwa besarnya nilai $\mathrm{Z}$ adalah -2,286 dengan nilai signifikan ( $p=$ value) sebesar 0,022 dimana nilai probabilitas 0,022 kurang dari nilai $a<0,05$, maka dengan ini hipotesis pada penelitian diterima, bahwa rerata produksi ASI ibu post partum kelompok kontrol yaitu 0,29 cc.
Tabel 3 Rerata Produksi Asi Pada Ibu Postpartum Kelompok Intervensi Dan Kelompok Kontrol (Sumber : Data Primer, 2021)

\begin{tabular}{|c|c|c|c|c|}
\hline $\begin{array}{l}\text { Kelompok } \\
\text { Intervensi }\end{array}$ & $\begin{array}{l}\text { Mean Rank } \\
20,40\end{array}$ & $\begin{array}{l}\text { Sum } \\
\text { Ranks } \\
306\end{array}$ & $\begin{array}{l}Z \\
-\end{array}$ & $\begin{array}{l}p \\
\text { value }\end{array}$ \\
\hline Kontrol & 10,60 & 159 & 3,058 & 0,002 \\
\hline
\end{tabular}

Berdasarkan analisa mann whitney test untuk mengetahui perbedaan rata-rata produksi ASI pada ibu post partum kelompok intervensi dan kelompok kontrol diperoleh besarnya $\mathrm{Z}$ yaitu sebesar $-3,058$ dengan $\mathrm{p}$ value $0,002<\alpha(0,05)$, yang berarti $\mathrm{H}_{0}$ ditolak. Maka dapat disimpulkan bahwa terdapat perbedaan rata-rata produksi ASI ibu post partum pada kelompok intervensi dengan kelompok kontrol.

\section{PEMBAHASAN}

Berdasarkan hasil penelitian yang dilakukan pada bulan April-Juni 2021 di PMB Lusi Kabupaten Bandung, terdapat perbedaan rerata produksi ASI yang signifikan antara kelompok yang diberikan tindakan pijat Woolwich dan kelompok yang tidak diberikan tindakan pijat Woolwich. Total responden sebanyak 30 orang yang dibagi menjadi dua kelompok yaitu 15 orang pada kelompok intervensi dan 15 orang pada kelompok kontrol

\section{1) Rerata Produksi ASI Pada Ibu PostPartum 6 Jam Kelompok Intervensi Di PMB Lusi Kabupaten Bandung Pada Tahun 2021 \\ Hasil penelitian menunjukkan bahwa dari $15 \mathrm{ibu}$} postpartum pada kelompok intervensi setelah dilakukan pijat woolwich, rerata produksi ASI adalah 0,68 cc. Hasil penelitian ini menunjukkan adanya peningkatan jumlah produksi ASI setelah diberikan pijat woolwich. Penelitian ini sesuai dengan penelitian Sukriana (2019) yang menemukan bahwa rata-rata produksi ASI setelah pijat lenwich adalah 80,92 ml dengan p-value 0,000, maka dapat disimpulkan bahwa pada kelompok eksperimen terdapat perbedaan volume ASI setelah dipijat dengan wollwich.

Berdasarkan teori yang dikemukakan oleh Sulistyawati (2012), produksi ASI bisa dipengaruhi oleh berbagai hormone seperti estrogen progesterone dan prolaktin. Selama masa kehamilan, hormon estrogen dan progesteron menginduksi perkembangan alveoli dan duktus lactiferous di dalam payudara, serta merangsang produksi kolostrum. Produksi ASI tidak berlangsung sampai masa sesudah kelahiran bayi ketika kadar hormon estrogen menurun. Penurunan kadar estrogen ini memungkinkan naiknya kadar prolaktin dan produksi ASI. Produksi prolaktin yang berkesinambungan disebabkan oleh menyusunya bayi pada payudara ibu. Pelepasan ASI berada dibawah kendali neuro-endokrin. Rangsangan 
sentuhan pada payudara (bayi menghisap) akan merangsang produksi oksitoksin yang menyebabakan kontraksi sel-sel myoepithel. Hisapan bayi memicu pelepasan ASI dari alveolus mamae melalui duktus kesinus lactiferous. Hisapan merangsang produksi okstoksin oleh kelenjar hypofisis posterior. Oksitoksin memasuki darah dan menyebabkan kontraksi sel-sel khusus (sel-sel myoepithel) yang mengelilingi alveolus mamae dan duktus lactiferous. Kontraksi sel-sel khusus ini mendorong ASI keluar dari alveoli melalui duktus lactiferous, tempat ASI akan disimpan. Pada saat bayi menghisap, ASI di dalam sinus tertekan keluar, kemulut bayi.

2) Rerata Produksi ASI Pada Ibu PostPartum 6 Jam Kelompok Kontrol Di PMB Lusi Kabupaten Bandung Pada Tahun 2021

Hasil penelitian menunjukkan bahwa dari $15 \mathrm{ibu}$ postpartum pada kelompok kontrol yang sudah diberikan tindakan massage payudara, rerata produksi ASI adalah 0,29 cc. Hal ini menunjukkan bahwa ada peningkatan produksi ASI pada ibu post partum kelompok kontrol setelah pemberian intervensi meskipun tidak diberikan perlakuan pijat woolwich, dari rerata produksi ASI 0,25 sebelum perlakuan menjadi 0,29 setelah perlakuan. Peningkatan ASI pada responden kelompok kontrol ini juga dapat dikarenakan saluran susu ibu tidak lagi tersumbat karena ASI sudah dikeluarkan sebelum diberikan perlakuan, sehingga ASI dapat keluar dengan lancar. Walaupun demikian, produksi ASI lebih banyak dihasilkan dari responden yang diberikan tindakan pijat woolwich dibandingkan dengan yang tidak diberikan tindakan pijat woolwich.

Hal ini sesuai dengan penelitian Pamuji (2014), berdasarkan hasil penelitiannya, nilai rerata peningkatan kadar hormon prolaktin pasca prosedur Woolwich massage pada kelompok intervensi juga lebih besar dibandingkan kelompok intervensi. kelompok kontrol. sebagai volume ASI pasca operasi pada kelompok intervensi pijat. lenwich memiliki nilai rata-rata yang lebih tinggi daripada kelompok kontrol.

Menurut pengamatan peneliti di lapangan, hal ini terjadi karena keadaan emosi seorang ibu, seperti cemas, stres, takut tidak bisa menyusui, atau takut mengganggu jadwal tidur bayinya, membuat bayinya sulit menyusui. Intervensi pijat Lenwich merangsang pelepasan endorfin. Endorfin adalah molekul protein yang diproduksi oleh sel-sel sistem saraf dan bagian tubuh tertentu, yang berguna dalam bekerja dengan reseptor untuk menghilangkan rasa sakit dan stres (Liberty Barokah, 2017).

Endorphin merupakan senyawa yang menenangkan dan hormon ini memproduksi empat kunci bagi tubuh dan pikiran, diantaranya mengurangi rasa sakit dan menghilangkan stres (Aprillia, 2010).

3) Rerata Produksi ASI Pada Ibu PostPartum 6 Jam Kelompok Intervensi dan Kelompok Kontrol Di PMB Lusi Kabupaten Bandung Pada Tahun 2021

Berdasarkan analisa mann whitney test untuk mengetahui perbedaan rerata produksi ASI sesudah pemberian pijat woolwich pada ibu post partum kelompok intervensi dan kelompok kontrol diperoleh besarnya $\mathrm{Z}$ yaitu sebesar $-3,058$ dengan $p$ value 0,002 $<\alpha(0,05)$, yang berarti $\mathrm{H}_{0}$ ditolak. Hal ini berarti terdapat perbedaan rerata produksi ASI pada ibu post partum antara kelompok intervensi dengan kelompok kontrol. Maka dapat disimpulkan bahwa terdapat pengaruh pijat woolwich terhadap produksi ASI pada ibu postpartum di PMB Lusi Kabupaten Bandung pada tahun 2021.

Hasil penelitian ini sejalan dengan hasil penelitian yang dilakukan oleh Sukriana (2018), hasil analisis menunjukkan bahwa rata-rata volume ASI setelah perlakuan pijat lenwich pada kelompok eksperimen adalah 80,92 $\mathrm{ml}$ dengan standar deviasi. adalah ,33 ml, sedangkan rata-rata volume ASI kelompok kontrol adalah 66,82 $\mathrm{ml}$ dengan standar deviasi ,39 $\mathrm{ml}$. Perbedaan nilai rata-rata setelah pengujian antara kelompok eksperimen dan kontrol adalah $1,1 \mathrm{ml}$. Hasil analisis p-value $=0,000<\alpha(0,05)$, dapat disimpulkan bahwa ada pengaruh pijat Woolwich terhadap produksi ASI dan ada perbedaan produksi ASI antara kelompok intervensi dan kontrol.

Hasil penelitian lain juga menguatkan kesimpulan penelitian yang dilakukan oleh peneliti yang sama bahwa penelitian yang dilakukan oleh Liberty Barokah menemukan bahwa terdapat perbedaan yang signifikan $(\mathrm{p}=0,012$ dan $<$ ) pada produksi ASI $(\mathrm{p}=0,012$ dan $<)$ berat badan bayi. ) antara kelompok kontrol (3021,88 \pm $159,88)$ dan kelompok perlakuan $(3265,63 \pm 320,79)$ setelah diberi perlakuan pijat lenwich. Perbedaan ini diamati pada berat badan rata-rata yang lebih tinggi dari anak-anak pada kelompok perlakuan dibandingkan pada kelompok kontrol.

Berdasarkan teori yang dikemukakan oleh Wulandari (2014), selain memperlancar ASI, pijat Woolwich juga memberikan kenyamanan pada ibu nifas, mengurangi bengkak (engorgement), mengurangi sumbatan ASI, merangsang pelepasan hormon oksitosin, mempertahankan produksi ASI ketika ibu dan bayi sakit. Selain aman dan mudah untuk dilakukan, pijat woolwich juga lebih bagus dibandingkan teknik pemijatan ASI lainnya. Hal ini karena pijat Woolwich merupakan salah satu alternatif untuk meningkatkan kenyamanan dan relaksasi ibu postpartum selama masa menyusui, sehingga dapat meningkatkan volume ASI. Metode pijat Woolwich juga memberikan stimulasi refleks pembentukan ASI 
(prolaktin reflex) dan pengeluaran ASI (let down

\section{SIMPULAN}

Berdasarkan hasil penelitian dan pembahasan mengenai pengaruh pijat woolwich terhadap produksi ASI pada ibu postpartum di PMB Lusi Kabupaten Bandung pada tahun 2021, maka peneliti menyimpulkan bahwa rerata produksi ASI pada ibu postpartum 6 jam kelompok intervensi yaitu $0,68 \mathrm{cc}$; rerata produksi ASI pada ibu postpartum 6 jam kelompok kontrol yaitu 0,29cc dan terdapat perbedaan rerata produksi ASI yang dihasilkan antara ibu postpartum 6 jam pada kelompok intervensi dan kelompok kontrol di PMB Lusi Kabupaten Bandung pada tahun 2021 dengan $p$-value $0,002<\alpha(0,05)$.

\section{UCAPAN TERIMAKASIH}

Terima kasih kepada LPPM Ikes Rajawali yang telah mendukung artikel ini.

\section{DAFTAR PUSTAKA}

Ahmad Rif'an, W. (2017). PEMBERIAN BACK ROLLING

MASSAGE DAN WOOLWICH MASSAGE TERHADAP KECEPATAN EKSKRESI ASI PADA IBU POST PARTUM DENGAN SECTIO CAESAREA. Jurnal Poltekkes Kemenkes Semarang. STIKES Telogorejo Semarang.

Astuti, S., Judisiani, T, D, dkk. (2015). asuhan kebidanan nifas dan menyusui. jakarta.

Badrus, A. R. (Juni 2018). Perbedaan Massage Woolwich Dan Massage Rolling (Punggung) Terhadap Peningkatan Produksi Asi Pada Ibu Postpartum. Jurnal Ilmiah : J-HESTECH, Vol. 1 No. 1,, 43- 49.

D, M. (2017). asuhan kebidanan pada ibu nifas. Yogyakarta: Gosyen Publishing.

Endah Tri Wahyunil, R. N. (Desember 2019). PEMANFAATAN WOOLWICH MASSAGE TERHADAP. Jurnal Kesehatan Madani Medika, Vol 10, No 2, 100-106.

Fraser, D. M., \& Cooper, M. A. (2011). buku ajar bidan. jakarta: egc.

Hidayat, A. A. (2014). metode penelitian kebidanan dan teknik analisis data. jakarta: salemba medika.

Husniyah. (2017). pengaruh pijat oksitosin terhadap produksi ASI pada ibu nifas di Puskesmas Jetis kota Yogyakarta. Jurnal Ilmu Kesehatan Universitas Aisyiyah. reflex)

Juhar, L. (Maret 2015). perbandingan breast care dan pijat oksitosin terhadap produksi ASI pada ibu postpartum normal. Jurnal DK, vol.3/no.1.

kesehatan, d. (2019). profil kesehatan provinsi jawa barat.

Kristiyansari, W. (2011). ASI, menyusui dan sadari. Yogyakarta: Nuha Medika.

Kusumastuti, U. L. (Februari 2019). kombinasi pijat wollwich dan oksitosin terhadap produksi ASI ibu postpartum. Journal Health of Science, vol.12/no.1 Hal 60-66.

Liberty Barokah, M. F. (November 2017). PENGARUH PIJAT WOOLWICH TERHADAP PRODUKSI ASI. Pengembangan Sumber Daya Perdesaan dan Kearifan Lokal Berkelanjutan VII", 17-18.

Mariah Synder, L. R. (2010). Complementary \& Alternative Therapies in Nusing sixth edition. New York: Springer Publishing Company.

Marmi. (2017). asuhan kebidanan pada ibu nifas. Yogyakarta: Pustaka Pelajar.

No.HK01.07/MENKES/320, k. (2020). Standar Profesi Kebidanan.

Notoatmodjo, S. (2018). metode penelitian kesehatan ed.revisi. Jakarta: Rineka Cipta.

Novi Khaulia Nindi², A. P. (2016). PIJAT WOOLWICH UNTUK MEMPERLANCAR PRODUKSI ASI. STIKes Muhammadiyah Gombong, 1-6.

Nurjanah, S. M. (2013). asuhan kebidanan postpartum dilengkapi dengan asuhan kebidanan post sectio caesarea. Bandung: PT Refrika Aditama.

Pamuji, S. R. (2014). Pengaruh Kombinasi Metode Pijat Woolwich dan Endorphine Terhadap Kadar Hormon Prolaktin dan Volume ASI (Studi Pada Ibu Postpartum Di Griya Hamil Sehat Mejasem Kabupaten Tegal). BHAMADA, JITK, vol.5/no.1.

RI. (2019). Undang-Undang RI No.4 tahun 2019 tentang Kebidanan. Jakarta: RI.

RI, K. (2018). riset kesehatan dasar (riskesdas) . Jakarta: Badan Penelitian dan Pengembangan Kesehatan Kemenkes RI.

RI, K. (2020). Profil Kesehatan Indonesia Tahun 2019. Kemenkes RI. Jakarta.

Saryono. (2011). metodologi penelitian keperawatan. Purwokerto: UNSOED.

Siti Erniyati Berkah Pamuji1, S. S. (2014). PENGARUH KOMBINASI METODE PIJAT WOOLWICH DAN. Poltekkes Kemenkes Semarang, Universitas Diponegoro, 1-15.

Soetjiningsih, I. N. (2015). tumbuh kembang anak. Jakarta: Buku Kedokteran EGC.

statistik, b. p. (2018). data dan informasi pemberian ASI eksklusif di Indonesia.

Sukriana1, Y. I. (Juli-Desember 2018). EFEKTIVITAS PIJAT WOOLWICH TERHADAP PRODUKSI 
ASI POST PARTUM. JOM FKp, Vol. 5 No. 2 , 512-519.

U, R. (2015). mengenal ASI ekslusif. Jakarta: Trubus.

Varney, H. (2012). buku panduan asuhan nifas fisiologis edisi 2. Jakarta: EGC.

Widiyanti. (2015). Perbedaan Antara Dilakukan Piijatan Oksitosin Dan Tidak Dilakukan Pijatan Oksitosin Terhadap Produksi Asi Pada Ibu Nifas Di Wilayah Kerja Puskesmas Ambarawa. Jurnal AKBID Ngudi Waluyo Ungaran.

Yeds, H. S. (2013). nilai menyusui, Indonesia menyusui. jakarta: IDAI pp. 1-2.

Yeni Aryani1, Z. H. (Mei 2019). PERBEDAAN PIJAT WOOLWICH DAN PIJAT OKSITOSIN TERHADAP KELANCARAN ASI PADA IBU NIFAS HARI KE 1 - 3 DI PRAKTIK MANDIRI BIDAN DINCE SAFRINA KOTA PEKANBARU. Jurnal Ibu dan Anak. Volume 7, Nomor 1, 10-16. 